
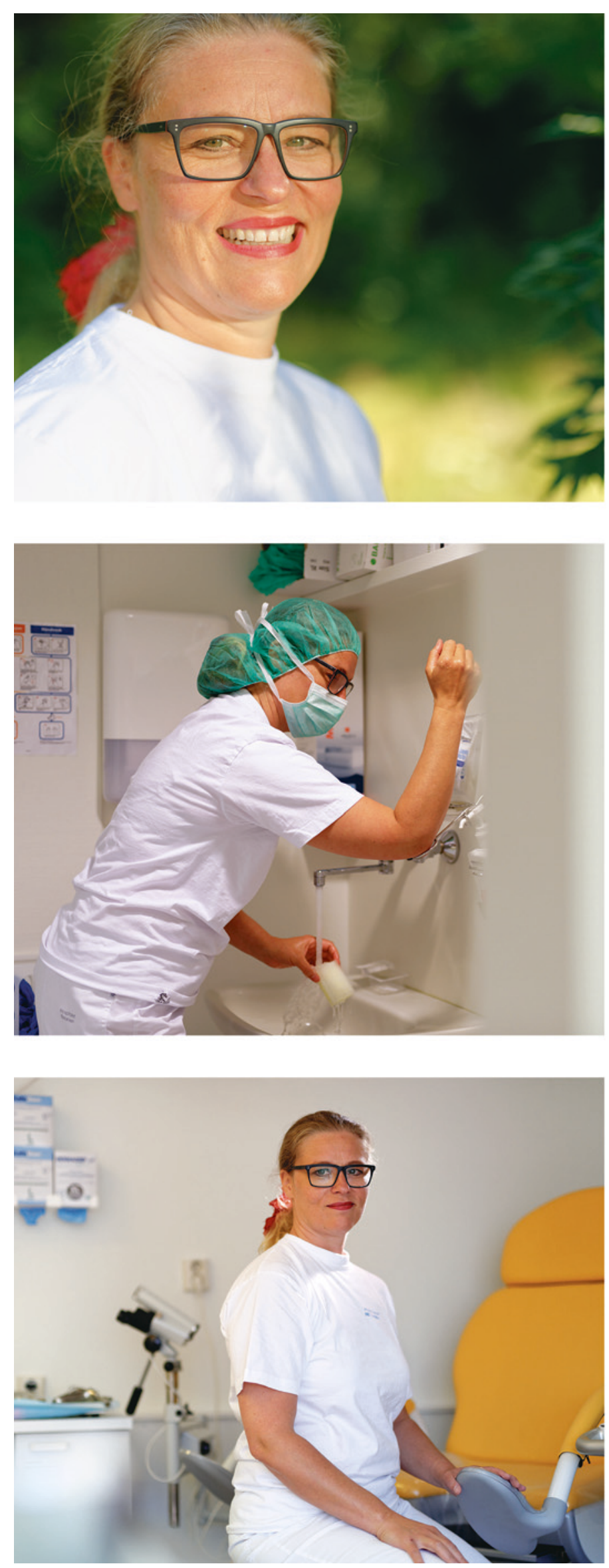

Foto: Magne Sandnes

\section{Bekkensmerter fram i lyset}

Mette Løkeland er ph.d. og spesialist i fødselshjelp og kvinnesjukdomar. Ho er overlege ved dagkirurgisk senter, Betanien sykehus, har ei bistilling som overlege ved Abortregisteret, Folkehelseinstituttet, og er nettredaktør for Norsk gynekologisk forening.

\section{Skjer det noko interessant innan gynekologien for tida?}

Kroniske, ikkje-sykliske bekkensmerter i meir enn 3-6 månader er ein ganske hyppig plage. Diverre har det ikkje vore eit prioritert forskingsfelt, men sidan 2013 har det vore arrangert to verdskongressar om emnet, seinast i juni i år. Gynekolog Unni Kirste har vore primus motor innafor feltet i Noreg. Estimata varierer - med prevalenstal frå $7 \%$ til $27 \%$ i befolkninga. Ved kroniske låge abdominalsmerter og bekkensmerter er det i tillegg til grundig anamnese viktig å palpere muskulaturen i bekkenet som ledd i utgreiinga. Årsaker til smertene kan vere mange og mangefasetterte. Dei fleste får primære eller sekundære muskulære smerter slik at moderering av desse ved hjelp av fysioterapi stort sett er indisert. Derimot er effekten av kirurgi meir usikker.

\section{Vil du tilrå ein ny og spanande artikkel?}

Det kom ein oversiktsartikkel om behandling for kroniske, ikkjesykliske bekkensmerter i tidsskriftet Obstetrical and Gynecological Survey i 2012 (1). Cecilie Hagemann gjorde i samband med sin disputas ved Norges teknisk-naturvitenskapelige universitet også ei god oppsummering av det same. Ein finn at kirurgisk behandling som til dømes adheranselosning har lite effekt. Hormonell behandling har derimot effekt, men inga var sikkert betre enn ei anna.

\section{Kva er ditt favoritthjelpemiddel på jobb?}

Dei faglege veiledarane på nettsida til Norsk gynekologisk forening er hyppig besøkt, i tillegg til Felleskatalogen på nett og KITH/Finn kode. Når det gjeld kroniske bekkensmerter, konsulterer eg ofte ljosbilde eg har fotografert av på kongressar.

\section{Litteratur \\ 1. Yunker A, Sathe NA, Reynolds WS et al. Systematic review of therapies for noncyclic chronic pelvic pain in women. Obstet Gynecol Surv 2012; 67: 417-25.}

Har du tips til personar vi kan intervjue? Ta kontakt med lise.morkved.helsingen@legeforeningen.no 